\title{
Small Pilot Survey on Parents' Perception of the Relationship between Children and Pets
}

\author{
Natalia Russo, Diana Vergnano *, Domenico Bergero and Liviana Prola \\ Department of Veterinary Science, University of Turin, 10095 Grugliasco, Italy; natalia.russo@unito.it (N.R.); \\ domenico.bergero@unito.it (D.B.); liviana.prola@unito.it (L.P.) \\ * Correspondence: diana.vergnano@unito.it; Tel.: +39-011-670-9210 \\ Academic Editor: Patrick Butaye \\ Received: 20 July 2017; Accepted: 10 October 2017; Published: 16 October 2017
}

\begin{abstract}
Since companion animals are taking on more important roles in family life, the aim of this study was to evaluate the perception of parents about the relationship between their children and pets. A number of parents were asked to fill in a questionnaire; the principal topics were: pet ownership, pet care, relationship between pets and children, and sources of information about pet management. Eighty-two parents completed the survey; $71.4 \%$ of them already had pets before having children; pet care and health has emerged to be rather important, since $96.4 \%$ of the pets are taken to the veterinarian at least once a year; moreover, the great majority of the parents $(97.2 \%)$ were not worried about the possible risks, linked to pets, pertaining to their child's health. The present survey confirms that pets are mostly considered as members of the family, and not only as a benefit for the children. Moreover, the relationship between children and pets is basically seen as a positive experience for children.
\end{abstract}

Keywords: children; parent perception; pets

\section{Introduction}

The number of pets in Italy has been estimated to be around 60 million [1], while there are about 8.1 million children under 14 [2]. It has emerged, from recent literature, that the role of pets has changed over the years. According to Walsh (2009) [3], companion animals are an important part of family life and are often treated as family members. Furthermore, different studies have pointed out the role that pets play in people's health [4-6]. However, most of these studies have focused on adults, while much less is known about the role of companion animals related to children in the family environment. On one hand, pets are thought to give both physiological and psychological health support, but on the other hand, they can represent a risk as far as bites and zoonosis are concerned [7,8]. A few studies have reported the perceptions of the children themselves about having a pet $[9,10]$. To the best of the authors' knowledge, there is only one study about the parental perception of the relationship between pets and their children [11] and it focused on play and care behaviors. Raising a child with pets can lead to many benefits; however, having a pet in the family is not always easy, since many problems can emerge, and families do not always have the right knowledge to manage them. Therefore, the aim of our work was to investigate how pets are perceived in Italian families and especially how the relationship between the children and their pets is perceived by the parents.

\section{Materials and Methods}

\subsection{Data Collection and Selection of the Participants}

A questionnaire was drawn up. The questionnaire was distributed online using social networks. It was addressed to parents of children under 14 years of age. Moreover, the parents had to own one or 
more pets, or at least have planned to have a pet in the future. Before sending in the questionnaire, the participants had to answer all the questions.

\subsection{Questionnaire Setup}

The survey was composed of 16 multiple-choice questions, which are reported in Table 1. The questions covered the following themes: pet ownership \& animal care, parent-pet relationship, child-pet relationship, and health risks linked to pets. Furthermore, the parents were asked whether they believed that they had all the information necessary to correctly manage the relationship between their pet and their children and whether they would ask or had asked for the veterinarian's advice before choosing their pet.

Table 1. Survey.

\begin{tabular}{|c|c|}
\hline $\begin{array}{l}\text { 1. Do you have any pets? } \\
\square \quad \text { Yes } \\
\square \quad \text { No }\end{array}$ & $\begin{array}{l}\text { 9. If so, how did the relationship change? } \\
\square \quad \text { It is better now, my pet receives more attention } \\
\square \quad \text { It is worse now, the time spent together } \\
\text { has decreased } \\
\square \quad \text { It is worse now, I am worried when my child } \\
\text { plays with our pet }\end{array}$ \\
\hline $\begin{array}{l}\text { 2. What kind of animal do you have/would } \\
\text { you like? } \\
\square \quad \text { Dog } \\
\square \quad \text { Cat } \\
\square \quad \text { Dogs and cats }\end{array}$ & $\begin{array}{l}\text { 10. How do you consider the relationship } \\
\text { between your child and your pet? } \\
\square \quad \text { Positively, they are playmates } \\
\square \quad \text { Positively, the child learns/is learning to take } \\
\text { care of someone } \\
\square \quad \text { Negatively, it can be risky }\end{array}$ \\
\hline $\begin{array}{ll}\text { 3. } & \text { How do you feed your pet(s)? } \\
\square \quad \text { Commercial diet } \\
\square \quad \text { Homemade diet } \\
\square \quad \text { Mixed diet (commercial + homemade diets) } \\
\square \quad \text { Commercial diet, but as natural as possible }\end{array}$ & $\begin{array}{l}\text { 11. Are you worried about the health of your } \\
\text { child as a result of owning a pet? } \\
\square \quad \text { Yes } \\
\square \quad \text { No }\end{array}$ \\
\hline $\begin{array}{l}\text { 4. Do you treat your pet for external parasites? } \\
\square \quad \text { Yes } \\
\square \quad \text { No }\end{array}$ & $\begin{array}{l}\text { 12. If so, what are you most worried about? } \\
\square \quad \text { Bites and scratches } \\
\square \quad \text { Hygiene issues } \\
\square \quad \text { Health risks (parasites, infections ... ) } \\
\end{array}$ \\
\hline $\begin{array}{l}5 . \quad \text { How many times per year do you take your pet } \\
\text { to the veterinarian? } \\
\square \quad \text { Once } \\
\square \quad \text { Twice } \\
\square \quad \text { Three times or more } \\
\square \quad \text { Never } \\
\end{array}$ & $\begin{array}{l}\text { 13. Since the birth of your child, have you } \\
\text { increased the number of veterinary appointments? } \\
\square \quad \text { Yes } \\
\square \quad \text { No }\end{array}$ \\
\hline $\begin{array}{l}\text { 6. Would you ask for your veterinarian's advice } \\
\text { before choosing your pet? } \\
\square \quad \text { Yes } \\
\square \quad \text { No }\end{array}$ & $\begin{array}{l}\text { 14. Do your children and pets share the } \\
\text { same spaces? } \\
\square \quad \text { Yes } \\
\square \quad \text { No }\end{array}$ \\
\hline $\begin{array}{l}\text { 7. When your child was born, did you already } \\
\text { have a pet? } \\
\square \quad \text { Yes } \\
\square \quad \text { No }\end{array}$ & $\begin{array}{ll}\text { 15. Do they sleep together? } \\
\square \quad \text { Yes } \\
\square \quad \text { No }\end{array}$ \\
\hline $\begin{array}{l}\text { 8. If so, when your child was born, did your } \\
\text { relationship with your pet change? } \\
\square \quad \text { Yes } \\
\square \quad \text { No }\end{array}$ & $\begin{array}{l}\text { 16. Do you think the information you have about } \\
\text { the management of your pet with regard to the } \\
\text { relationship with your child is sufficient? } \\
\square \quad \text { Yes } \\
\square \quad \text { No }\end{array}$ \\
\hline
\end{tabular}




\subsection{Statistical Analysis}

A descriptive statistic has been proposed for this pilot study. The answers were tabulated using a commercial program (Microsoft Excel 2010, Microsoft, Redmond, WA, USA) and the results were expressed as percentages.

\section{Results}

A total of 110 questionnaires were sent out, of which 82 parents completed the survey.

A total of $86.1 \%$ of the parents had pets: $52 \%$ of them only owned a dog, $16 \%$ only owned a cat, and $32 \%$ owned several animals. As far as the questions about animal care is concerned, $56.1 \%$ of the parents declared they fed their pets commercial diets $3.7 \%$ of them searched for the most natural commercial feeds); $36.6 \%$ instead fed them a mixed diet, while $7.3 \%$ fed homemade food. A total of $84.1 \%$ of the families treated their pets for external parasites. Most pets $(62.2 \%)$ were taken to the veterinarian once a year, $25.6 \%$ were taken twice a year, $8.6 \%$ three or more times per year, and $3.6 \%$ were never taken. A total of $51.2 \%$ declared they asked a veterinarian for advice about their choice of animal.

A total of $72 \%$ already had a pet before having children. Furthermore, the majority of the participants $(71.9 \%)$ declared that their relationship with their pet had not changed after the arrival of the baby; in $56.5 \%$ of the cases in which the relationship had changed, it had improved. The relationship between the children and the pets was considered positive by all of the parents ( $70.7 \%$ stated the pet was a playmate, while $29.3 \%$ declared it was someone to take care of). The great majority of the parents $(97.5 \%)$ declared they were not worried about the possible health risks for the children linked to the presence of animals: in fact, only $1.2 \%$ of the parents were worried about hygiene and $1.2 \%$ about sanitary risks. Moreover, most had not increased the number of visits to the vet after their child's birth (only $3.7 \%$ had). Instead, $80.5 \%$ of the children shared the same rooms with the animals, even though only $30.5 \%$ slept with them.

Finally, $90.2 \%$ of the parents declared they did not need any further information about the child-pet relationship.

\section{Discussion}

In our study, the percentage of parents with a household pet, $86.1 \%$, is higher compared to percentage found by other authors [12] where parents with a pet where $54.8 \%(n=746)$; anyway, the difference could also be due to the different sample size In our data, the percentage of families that owned only a dog $(52 \%)$ was higher than the percentage that owned only a cat $(16 \%)$ and the percentage that owned several animals (32\%). In another study developed in Italy in 2008 by Slater and colleagues [13], the percentage found for cats was similar, while that found for dogs was lower: $15 \%$ had cats $(60 / 397)$ and $33 \%(130 / 397)$ had dogs. The higher percentage of dogs in families with children could be due to the behavioral characteristics of this species, which makes them more suitable for interacting with children, especially small children.

The majority of the families (59.8\%) only fed their pet commercial diets. This finding is in agreement with the Assalco survey 2017 [1], which reports that $77 \%$ of the interviewed use commercial feeds. Pet's health seems to be quite important: $96.4 \%$ of the pets were taken to veterinarian at least once a year, and $84.1 \%$ of the families treated their pets for parasites.

Regarding the child-pet relationship, the present survey shows that pets are generally considered as family members and not only as a benefit for the child, since, in the majority of the cases $(71.4 \%)$, the pet was acquired before the birth of the child. The animals are not considered dangerous for the child's health and they are perceived to have a role in improving relationship capacities and responsibility. This is in agreement with what Catcher and Friedman stated in 1982 [14]. They suggested seven main roles for pets, including companionship and someone to care for. 
A total of $90.9 \%$ of the parents that were interviewed believed they already had all the information necessary about the relationship between children and pets; nearly half of the parents asked their veterinarian for advice about the choice of animal, but no information is available about the other sources. It would be interesting to focus more on this point in order to verify whether these sources are reliable and complete.

\section{Conclusions}

In conclusion, the antenatal and postnatal presence of furry household pets has been demonstrated to confer protection against development of atopy, food sensitization, and metabolic disease [15-17] in children and has been linked to reduction of cardiovascular risk in infants [18]. With this study, we gave stimulating points for reflection, even if the sample was small, because the presence of household pets highlighted by our data is high compared to other data and could be interesting to investigate with a multidisciplinary approach, if it means lower presence of the above mentioned diseases in children population in the same area. It would be useful, therefore, to extend this survey to a bigger population in different parts of Italy and to investigate if there are differences between pet species (cat vs. dog).

Acknowledgments: All sources of funding of the study should be disclosed. Please clearly indicate grants that you have received in support of your research work. Clearly state if you received funds for covering the costs to publish in open access. Please provide this section if necessary.

Author Contributions: Natalia Russo and Diana Vergnano contributed equally to the work. Domenico Bergero and Liviana Prola conceived and designed the experiments; Natalia Russo and Diana Vergnano performed the experiments; Natalia Russo and Diana Vergnano analyzed the data; Diana Vergnano and Liviana Prola wrote the paper.

Conflicts of Interest: The authors declare no conflict of interest.

\section{References}

1. Assalco-Zoomark, 2017 Report-On the Feeding and Care of Pets. Available online: http://www.assalco.it/ index.php?action=shownews\&id=1\&nid=6756 (accessed on 6 April 2017).

2. Istat (National Institut of Statistics) Annual Report 2017. Available online: https://www.istat.it/it/files / 2017/05/RapportoAnnuale2017.pdf (accessed on 6 April 2017).

3. Walsh, F. Human-animal bonds II: The role of pets in family systems and family therapy. Fam. Process 2009, 48, 481-499. [CrossRef] [PubMed]

4. Dotson, M.J.; Hyatt, E.M. Understanding dog-human companionship. J. Bus. Res. 2008, 61, 457-466. [CrossRef]

5. Barker, S.; Wolen, A.R. The benefits of human-companion animal interaction: A review. JVME 2008, 35, 487-495. [CrossRef] [PubMed]

6. Westgarth, C.; Liu, J.; Heron, J.; Ness, A.R.; Bundred, P.; Gaskell, R.M.; German, A.J.; McCune, S.; Dawson, S. Dog ownership during pregnancy, maternal activity, and obesity: A cross-sectional study. PLoS ONE 2012, 7. [CrossRef] [PubMed]

7. Westgarth, C.; Heron, J.; Ness, A.R.; Bundredm, P.; Gaskellm, R.M.; Coynem, K.P.; German, A.J.; McCune, S.; Dawson, S. Family pet ownership during childhood: Findings from a UK birth cohort and implications for public health research. Int. J. Environ. Res. Public Health 2010, 7, 3704-3729. [CrossRef] [PubMed]

8. Orritt, R. Dog ownership has unknown risks but known health benefits: We need evidence based policy. BMJ 2014, 349, 1-2. [CrossRef] [PubMed]

9. Westgarth, C.; Boddy, L.M.; Stratton, G.; German, A.J.; Gaskell, R.M.; Coyne, K.P.; Bundred, P.; McCune, S.; Dawson, S. Pet ownership, dog types and attachment to pets in 9-10 year old children in Liverpool, UK. BMC Vet. Res. 2013, 9, 102-112. [CrossRef] [PubMed]

10. McNicholas, J.; Collis, G.M. Children's representations of pets in their social networks. Child Care Health Dev. 2001, 27, 279-294. [CrossRef] [PubMed]

11. Melson, G.F.; Fogel, A. Parental perceptions of their children's involvement with household pets: A test of a specificity model of nurturance. Antrozoos 1996, 9, 95-106. [CrossRef] 
12. Tun, H.M.; Konya, T.; Takaro, T.K.; Brook, J.R.; Chari, R.; Field, C.J.; Guttman, D.S.; Becker, A.B.; Mandhane, P.J.; Turvey, S.E.; et al. Exposure to household furry pets influences the gut microbiota of infants at 3-4 months following various birth scenarios. Microbiome 2017, 5, 40. [CrossRef] [PubMed]

13. Slater, M.R.; Di Nardo, A.; Pediconi, O.; Villa, P.D.; Candeloro, L.; Alessandrini, B.; Del Papa, S. Cat and dog ownership and management patterns in central Italy. Prev. Vet. Med. 2008, 85, 267-294. [CrossRef] [PubMed]

14. Katcher, A.H.; Friedmann, E. Potential health value of pet ownership. Calif. Vet. 1982, 36, 9-13.

15. Azad, M.B.; Konya, T.; Guttman, D.S.; Field, C.J.; Sears, M.R.; HayGlass, K.T.; Mandhane, P.J.; Turvey, S.E.; Subbarao, P.; Becker, A.B.; et al. Infant gut microbiota and food sensitization: Associations in the first year of life. Clin. Exp. Allergy 2015, 45, 632-643. [CrossRef] [PubMed]

16. Molloy, J.; Allen, K.; Collier, F.; Tang, M.L.; Ward, A.C.; Vuillermin, P. The potential link between gut microbiota and IgE-mediated food allergy in early life. Int. J. Environ. Res. Public Health 2013, 10, 7235-7256. [CrossRef] [PubMed]

17. Azad, M.B.; Becker, A.B.; Guttman, D.S.; Sears, M.R.; Scott, J.A.; Kozyrskyj, A.L. Canadian Healthy Infant Longitudinal Development Study I. Gut microbiota diversity and atopic disease: Does breast-feeding play a role? J. Allergy Clin. Immunol. 2013, 131, 247-248. [CrossRef] [PubMed]

18. McCloskey, K.; Vuillermin, P.; Carlin, J.B.; Cheung, M.; Skilton, M.R.; Tang, M.L.; Allen, K.; Gilbert, G.L.; Ranganathan, S.; Collier, F.; et al. Perinatal microbial exposure may influence aortic intima-media thickness in early infancy. Int. J. Epidemiol. 2016, 46, 209-218. [CrossRef] [PubMed]

(C) 2017 by the authors. Licensee MDPI, Basel, Switzerland. This article is an open access article distributed under the terms and conditions of the Creative Commons Attribution (CC BY) license (http://creativecommons.org/licenses/by/4.0/). 